\title{
Selection of Dye Markers for Monitoring Reticulitermes speratus and Identification of Colonies by Heterogeneous Dye-Marking ${ }^{1}$ (OPR
}

\author{
Ik-Gyun $\mathrm{IM}^{3,4} \cdot$ Gyu-Seong HAN $\mathbb{D}^{2,4, \dagger}$
}

\begin{abstract}
To estimate the territorial size of Reticulitermes speratus, a species of subterranean termites that damages wooden structures in Korea, appropriate dye markers were selected and the diffusion tendency was analyzed. According to the results of the sensitivity assessment using sawdust diet, increase in dye concentration reduced the amount of feed consumption but the dyeing becomes more intense. Except for the Neutral Red $0.5 \%$ group, all other concentration groups, including the control group, showed a survival rate of $>85 \%$ until week 4 . For both, Nile Blue A and Neutral Red dye markers, all concentration conditions $>0.2 \%$, except for the $0.1 \%$ concentration, were maintained for 11 weeks, and no sign of transfer effect was found except when the termites were fed with the dye markers. Therefore, it appears that $0.2 \%$ of Nile Blue A and Neutral Red is the optimal concentration for monitoring the $R$ speratus colonies. Additionally, we prepared an indoor $40 \mathrm{~m}$ long foraging arena consisting of a colony of 25,000 termites and released individuals stained with $0.2 \%$ of Nile Blue A and Neutral Red at both ends to assess the diffusion trends over time. The results showed that it took approximately 7 days for each dyed individual to gradually cover the $40 \mathrm{~m}$ distance and mix with each other. These findings reveal that when mark-release-recapture monitoring is conducted on the $R$. speratus colonies damaging wooden structures, the extent of the colony's activity area could be measured and different colonies could be distinguished from each other.
\end{abstract}

Keywords: termite, Nile Blue A, Neutral Red, mark-release-recapture, foraging distance

\section{INTRODUCTION}

In a recent survey conducted from 2018 to 2019, in the 2,805 wooden heritage structures, 486 cases of subterranean termite infestations were discovered, of which $30 \%$ were ongoing. This finding indicates the continuous nationwide damage to the outdoor wooden heritage structures by subterranean termites (Im et al., 2021). The results from previous studies have confirmed that subterranean termites belonging to Reticulitermes spp. inflict damage to various wooden structures in Korea (Kim et al., 2010; Lee and Jeong, 2004; Chung et al., 2015; Lee et al., 2015). Owing to these characteristics of the subterranean termites, there has been

\footnotetext{
${ }^{1}$ Date Received August 4, 2021, Date Accepted August 31, 2021

2 Department of Wood and Paper Science, Chungbuk National University, Cheongju, 28644, Republic of Korea

${ }^{3}$ Department of Cultural Heritage Science, Chungbuk National University, Cheongju, 28644, Republic of Korea

${ }^{4}$ Heritage Science Center, Chungbuk National University, Cheongju, 28644, Republic of Korea

$\dagger$ Corresponding author: Gyu-Seong HAN (e-mail: wood@chungbuk.ac.kr, ORCID: 0000-0003-3835-2063)
} 
an increase in the structural damage to the wooden heritage structures, and the Risk Management Division of Animal and Plant Quarantine Agency has selected 28 termite species with a high risk of damage once domestic termite invasion and settlement occurs (Korea Forest Service, 2016). Additionally, the National Research Institute of Cultural Heritage under the Cultural Heritage Administration and the 23 Cultural Heritage Care Project groups in 17 cities/provinces are regularly monitoring the termite infestations in wooden heritage structures nationwide. These organizations are monitoring the subterranean termites through many methods, such as termite detection dogs, microwave detection devices, ultrasonic detection devices, video microscope, installation of wood specimens, and investigate trace of damages through visual observation (Cultural Heritage Care Support Project, 2019; Kim et al., 2019; Son and Lee, 2008).

However, these domestically employed termite monitoring methods have limitations in monitoring and controlling the size of the colonies and the extent of the activity area since the Reticulitermes speratus colonies that invade via tunneling under the ground near the targeted wooden structure cannot be determined using such measures. To solve these problems, in the late 1980s, inspection via monitoring stations was conducted overseas to detect the foraging territory to control the termite colonies ( $\mathrm{Su}$ et al., 1986; Grace, 1989, 1990; Thorne et al., 1996; Tsunoda et al., 1998, 1999) and various colored dye markers were applied to the collected specimens. In the early stages of dye-marker research (early 1980s), the marking effect of Sudan Red 7B based on concentration conditions was evaluated on majorly affecting species such as Coptotermes formosanus and Reticulitermes flavipes (Su et al., 1983, 1988; Grace and Abdallay, 1989). Additionally, the application of several other dye markers, such as Nile Blue A (Su et al., 1993; Grace, 1989, 1990; Forschler and Townsend, 1996; Thorne et al., 1996) and Neutral Red (Evans, 2000; Nobre et al., 2007) to Coptotermes formosanus and Reticulitermes flavipes have been studied since the 1990s. Moreover, Tsunoda et al. $(1998,1999)$ applied 0.05\% Nile Blue A to R. speratus to monitor the territory of the outdoor colony.

Meanwhile, to review the dye markers suitable for monitoring subterranean termites in Korea, Kim et al. (2014) investigated the survival rate, transfer effect, and appropriate concentrations of Nile Blue A on $R$. speratus. Furthermore, Kim et al. (2020) investigated the applicability of Nile Blue A on $R$. speratus. The key issue is that it lowered the overall survival rate because the restricted study environment was exposed to the atmosphere, which is different from the actual living conditions of the subterranean termite. Im and Han (2020) used Sudan Red 7B on R. speratus to devise an assessment method that considered the actual habitat environment of the subterranean termite. However, even at the highest concentration of Sudan Red 7B, the dye persistence was shown in $R$. speratus within 2 weeks, indicating that it was not suitable for dyeing for subterranean termite monitoring.

Therefore, in this study, the type and appropriate concentration of a dye marker to measure the extent of $R$. speratus territory was investigated using the assessment method established by Im and Han (2020). The range of the dye markers for evaluating the appropriate concentration was between $0.1 \%$ and $0.5 \%$. For the dye-marker evaluation, Nile Blue A, which has been investigated on $R$. speratus previously, was compared with Neutral Red, a new marker for $R$. speratus. Also, when the extent of the territory of the subterranean termite invading the wooden structures is monitored using the dye markers, it appears that a certain amount of time is required for the released individuals to spread evenly to all areas within the colony. Therefore, an indoor foraging arena was produced, and two dye markers were applied to 1,000 
individuals (Nile Blue A: 500 unit and Neutral Red: 500 unit) to observe the range of the spread area and the mixing patterns of the released individuals over time.

\section{MATERIALS and METHODS}

\subsection{Termite collection and DNA sequencing}

The termite-infested logs were collected from the forests in Goun-dong, Sejong City and Cheongju City, Chungcheongbuk-do and stored in containers in the laboratory. The study object separation method was modified from the established procedures of Judd and Fasnacht (2007) and Tamashiro (1973) as follows: Right before the start of the experiment, corrugated cardboard was placed in a storage container for a certain amount of time for the termites to move over to the cardboard so that they were separated without any decomposition of logs inside the containers.

Mitochondrial DNA (mtDNA) of the collected subterranean termites was extracted using DNeasy Blood \& Tissue Kit (SolGent Co., Ltd. Korea). Polymerase Chain Reaction (PCR) was performed using Takara PCR Thermal Cycler Dice TP600 (Takara Bio Inc., Japan) and the PCR primer sets used in this study were LCO-1490 and HCO-2198. To obtain the cytochrome oxidase I (COI) barcode sequence of the collected subterranean termite mtDNA, 2x Uh-taq PCR Pre-Mix (SolGent Co., Ltd., Korea) was used. COI sequence (658bp) was confirmed with GenBank and BOLD system (barcoded of the Life Data System). According to the results, the termites used in this study were identified as $R$. speratus.

\subsection{Marking and consumption of samples containing marking reagents}

Based on previous studies abroad, Nile Blue A (CAS Number: 3625-57-8, Sigma, St. Louis, Mo. USA) and Neutral Red (CAS Number: 553-24-2, Acros Organics, New Jersey, USA) were used (Nobre et al., 2007; Evans, 2000, 2006; Kim et al., 2020). The sample containing the marking reagents was produced according to the method of Im and Han (2020). Dye-marker concentration conditions for each type of dye in $R$. speratus were prepared by diluting the dye to $0.1 \%, 0.2 \%$, and $0.5 \%$ according to the weight ratio (wt/wt), as reported in previous studies related to dye-marker concentration on C. acinaciformis, C. lacteus, and R. grassei (Nobre et al., 2007; Evans, 2000).

The trial arena for marking was prepared as follows: $35 \mathrm{~g}$ of substrate prepared by mixing washed silica sand and distilled water in a ratio of 10:1 (wt/wt) was placed in a $90 \mathrm{~mm}$ Petri dish, and the sample containing the marking reagents was placed on it. Subsequently, 400 workers were added to the arena to be exposed under forced feeding (no-choice) conditions for 5 days. These termites were stained according to each concentration condition of the dye markers. Each experiment was conducted three times, five repetitions were performed for each condition, and the final value of the experiment was averaged from a total of 15 replicates.

Feeding amounts of the filter paper for 5 days in line with each concentration of a type of dye were measured. After 5 days of the feeding period, feed samples were collected, dried to a constant weight at $60^{\circ} \mathrm{C}$ in a dryer, and the weights were measured. The feeding amounts for the concentration conditions of each dye type were compared to investigate the feeding activities according to the concentration increase.

\subsection{Survival rate and retention time of marking reagent}

Survival rate per dye marker type and concentration condition were investigated. In this method, $25 \mathrm{~g}$ of silica sand containing moisture in the same condition described in 2.2 was placed in a $55 \mathrm{~mm}$ Petri dish. 
In terms of the feeding source, $5 \mathrm{~g}$ of sawdust diet containing a mixture of sawdust and cellulose powder, etc., was prepared according to Matsuura and Nishida (2001) and placed on top of the silica sand. Fifty conditionally marked workers, as described in 2.2 , were introduced. The container was covered with the lid and sealed with Parafilm to prevent evaporation of the moisture. Aeration and the replenishment of the sawdust diet were performed weekly. The number of replicates was 20 for each concentration condition, and 5 replicates were randomly selected each week to check the survival rates for 4 weeks. Additionally, to evaluate the marking persistence of each condition, the same study arena and marking methods were prepared as described in 2.2 for 200 workers to be deployed in each condition. For the feeding source, $5 \mathrm{~g}$ of sawdust diet was provided per week. Depending on the time progress and feeding activity, the marking persistence was measured using a stereoscopic microscope (Nicon, JSMZ800N, JPN). The shoot was conducted right after the marking at week 4 and week 8 for each condition by collecting the workers for each concentration condition.

\subsection{Transfer effect}

Marking reagent transfer between the marked and unmarked individuals by Trophallaxis was investigated. The concentration of both the dye markers, Nile Blue A and Neutral Red, was $0.2 \%$ for the marked individual. Therefore, 30 marked workers, 30 unmarked workers, and 3 unmarked soldiers were placed in a $55 \mathrm{~mm}$ Petri dish under the same survival assessment condition as 2.3. Sawdust diet was provided as the feeding source. Petri-dish aeration and sawdust diet feeding were provided once every week for 21 days, and simultaneously, the number of marked and unmarked workers was estimated and the marking transfer-effect trends of the soldiers were observed.

\subsection{Spread area coverage over time}

To confirm the applicability of the markers for investigating the extent of the activity area of the subterranean termite colony infesting the wooden structures and the area of the wooden heritage site, the foraging arena was produced to measure the spread area coverage over time of the marked individual. The arena was composed of four pathways for each direction based on the main nest, and each tube was about $5 \mathrm{~m}$ long. For each direction, four tubes were connected to make a $20 \mathrm{~m}$ long pathway, and the total length of both sides was $40 \mathrm{~m}$, with the main nest in the middle (Fig. 1, 2).

The main nest was a container of $100 \mathrm{~mm}$ diameter and $110 \mathrm{~mm}$ height containing $250 \mathrm{~g}$ of sawdust diet as a constant feeding source for the termite colony. Furthermore, for up to a height of $10 \mathrm{~mm}, 3.5 \%$ agar was poured on the top to suppress microbial germination on the sawdust diet surface to the best possible extent.

The shelter was composed of a $45 \mathrm{~mm}$ diameter and $85 \mathrm{~mm}$ height plastic cylinder column with a hole drilled at the center of the bottom surface and at a height

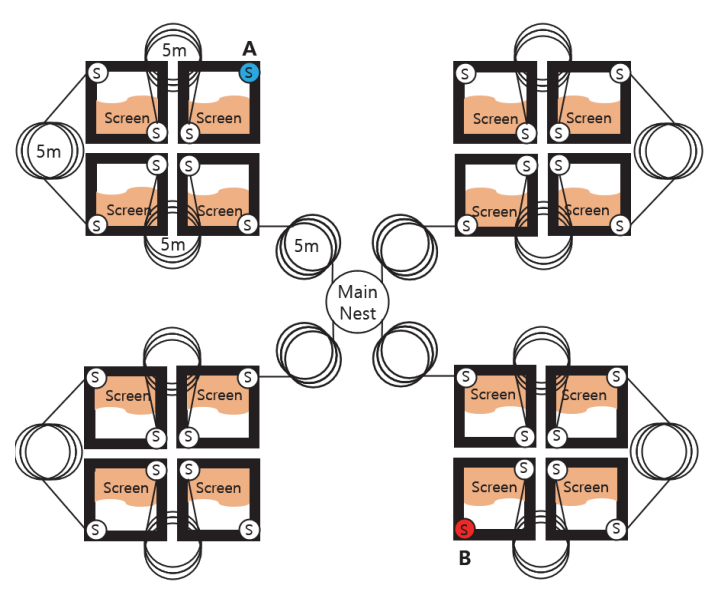

Fig. 1. Foraging arena for estimating the activity area (A: Release point of Nile blue A dyed individuals / B: Release point of Neutral Red dyed individuals). 


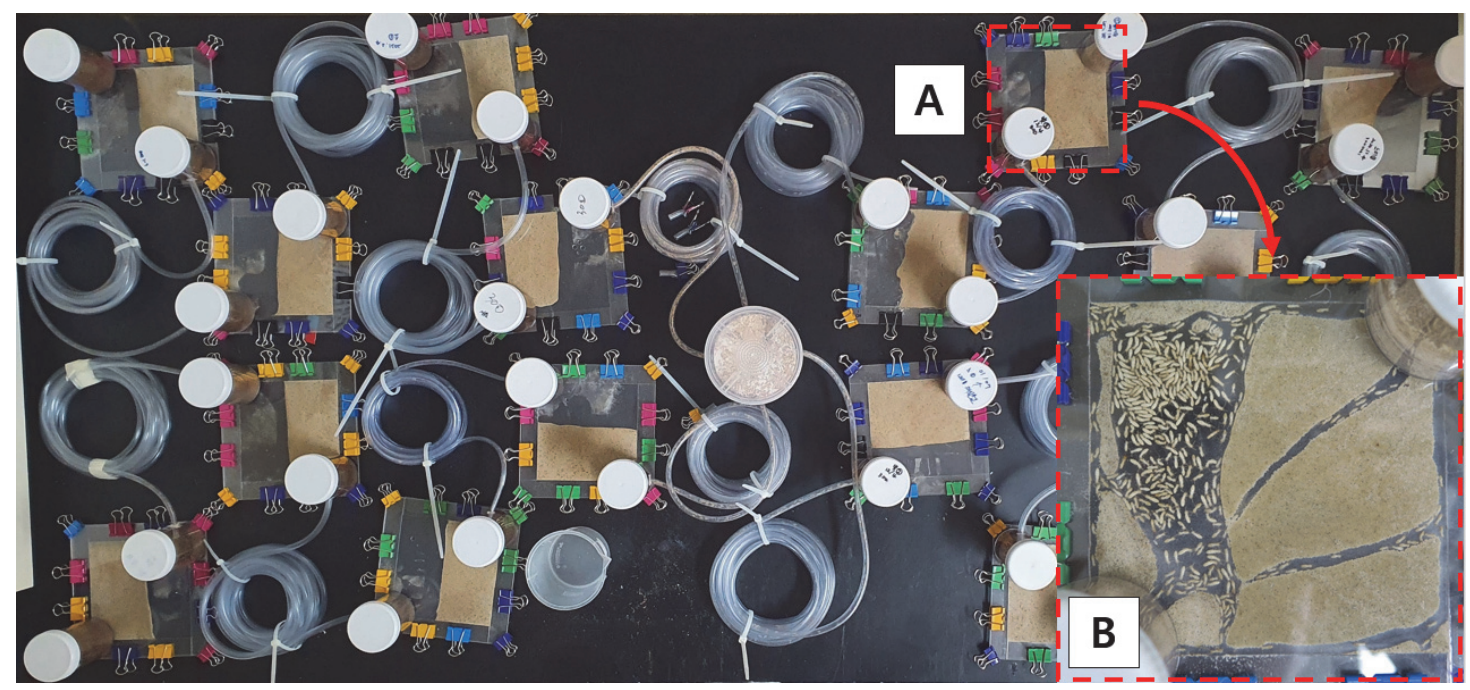

Fig. 2. Pathway of foraging arena for dyed termite (A: Before termite introduction / B: After termite introduction).

of $30 \mathrm{~mm}$ from the bottom surface (Fig. 1S). Shelters of $5 \mathrm{~m}$ each were installed at the corners of the planar arena as an intermediate habitat. Each shelter was filled with $30 \mathrm{~g}$ of sawdust diet to provide feeding source to maintain the activities. Agar was injected into the top of the feeding head, just like the main nest. A flexible plastic tube was connected to the hole of the shelter to produce an artificial pathway so that the whole arena was connected as a single colony. Planar arena, which was installed as a screen to observe the movement of the subterranean termites placed inside, was modified according to the features of $R$. speratus based on a method reported in previous studies on $C$. formosanus (Su, 2005; Chouvenc et al., 2011; Chouvenc, 2018). A transparent acrylic plate of $1 \mathrm{~mm}$ thickness was placed between two $2 \mathrm{~mm}$ thick transparent acrylic plates in a sandwich format to produce a space for the termite individuals to move actively inside. The upper $2 \mathrm{~mm}$ acrylic plate had a hole in the corner where it met the shelter for facilitating the entry of the termites. Moreover, $30 \mathrm{~g}$ of silica sand (Silica sand No 7 , Saeron Industry, KOR) injected with $10 \%$ distilled water was added to the inside of the planar arena. This process maintained the internal humidity so that the individuals can move actively along different shelters through the planar arena.

In the foraging arena, 25,000 of $R$. speratus colony was divided into 33 groups and placed in the main nest and shelters. After 25,000 R. speratus colony were introduced, it was monitored for 7 days to confirm the connection of the entire area. 500 individuals marked with $0.2 \%$ of Nile Blue A and Neutral Red were separated based on each color and placed in the shelters located at both ends of the planar arena (Fig. 1(A), 1(B)). Through this process, the spread area coverage of the marked individual for each day and the time taken to reach the opposite point, which was at a distance of $40 \mathrm{~m}$ from the input point, was measured. Five replicates were conducted to confirm the spreading tendency after Nile Blue A and Neutral Red were injected into one foraging arena.

\subsection{Data analysis}

Analysis of variance (ANOVA) was performed using the SPSS Statistics program (IBM SPSS Statistics 26, 
Selection of Dye Markers for Monitoring Reticulitermes speratus and Identification of Colonies by Heterogeneous Dye-Marking

USA) on the amount of feed consumption depending on the type and concentration conditions of the dye markers and the survival rate for each condition. When ANOVA demonstrated a significant difference between the average results of each treatment, different letters (a-e) were used for marking. For the post-hoc comparison analysis, Tukey's honestly significant difference post-hoc test was conducted. The results of the analysis are presented along with standard deviation $( \pm)$.

\section{RESULTS and DISCUSSION}

\subsection{Marking and feed consumption of sample containing marking reagent}

Nile Blue A and Neutral Red were used at concentrations of $0.1 \%, 0.2 \%$, and $0.5 \%$ to stain the termites for 5 days. The results suggested that when compared with the control group, it was possible to visually distinguish the marked individuals with naked eyes even when only $0.1 \%$ of both dyes were used (Fig. 3). This result is probably due to the accumulation of the fed dye markers within the trophocytes, the cells present in the fat bodies of the termites (Evans, 1997).

Very few unstained individuals were found during the 5 days of the staining period, which is thought to be caused by the pre-molting fasting or physio- logical reasons (Su et al., 1983).

Meanwhile, in all conditions, every soldier was marked by the transfer effect from the workers at the end of the 5 days of the staining period (Fig. 4). Just like the workers, the soldiers also demonstrated deeper marker color as the concentration increased since the workers transferred the marking reagent along with the other nutrients through the trophallaxis. Also, such a result is consistent with those from previous studies investigating the appropriate concentration of Nile Blue A on various species such as $R$. speratus, Coptotermes frenchi, C. lacteus, Nasutitermes exitiosus (Evans, 1997; Kim et al., 2020).

Even under the forced feeding (no-choice) condition, as the concentration of Nile Blue A and Neutral Red increased, feed consumption decreased depending on the concentration compared to the control group by $76 \% \sim 88 \%$ in the $0.1 \%$ concentration condition, $46 \% \sim 61 \%$ in the $0.2 \%$ concentration condition, and $18 \sim 29 \%$ in the $0.5 \%$ concentration condition (Fig. 5). Additionally, ANOVA showed that there was a difference in the amount of feed consumption between the control group and each concentration condition. These results suggest that both dyes, irrelevant of the type, had adverse effects on feed consumption depending on the concentration of the dye.

This trend is consistent with the findings of Im and
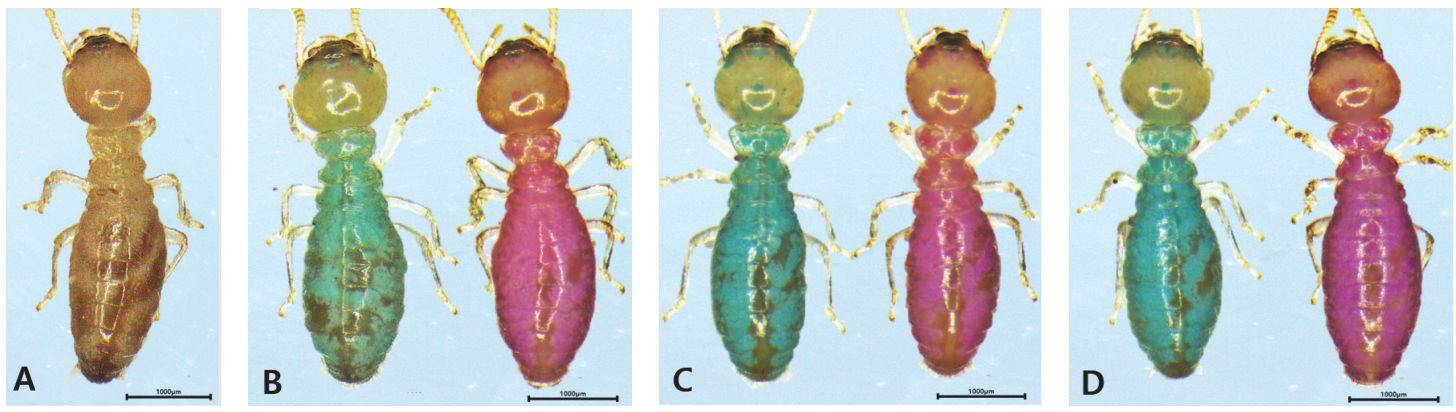

Fig. 3. Marking pattern according to the concentration of Nile Blue A and Neutral Red Deviation (A: Control B: $0.1 \%$ C: $0.2 \%$ D: $0.5 \%$ / Left: Nile Blue A, Right: Neutral Red). 

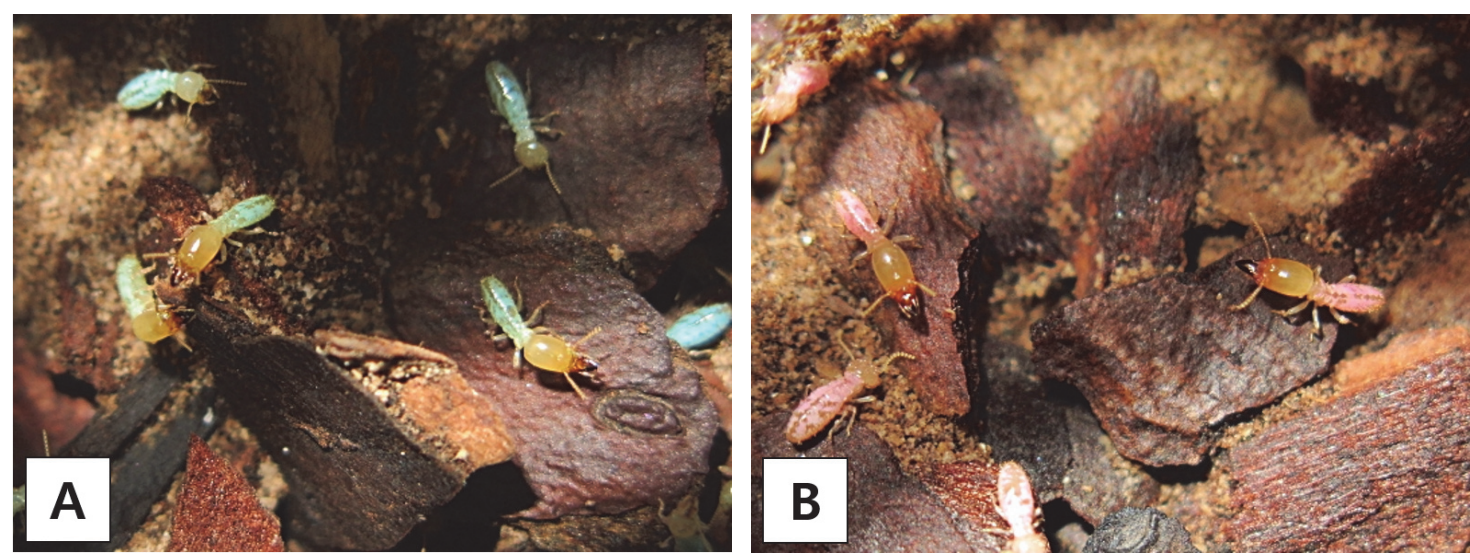

Fig. 4. Marking of soldier due to trophallaxis immediately after feeding (A: Nile Blue A / B: Neutral Red).

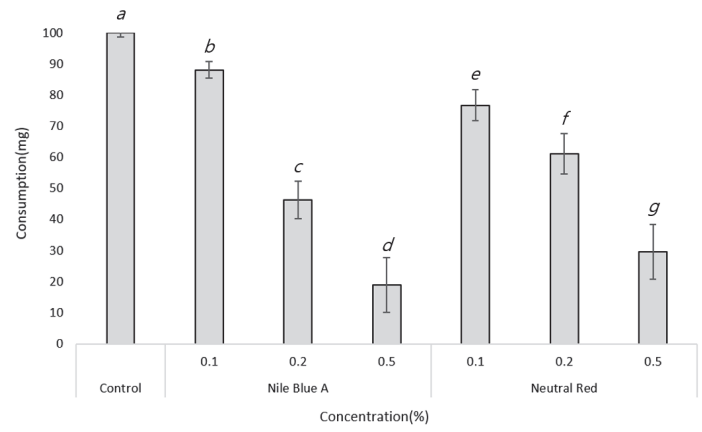

Fig. 5. Feed consumption (mean $\pm \mathrm{SD}$ ) according to the concentration of the marking reagent (ANOVA, Tukey post hoc test, $\alpha=0.05)$.

Han (2020), which demonstrated a reduction in the feed consumption of $R$. speratus as the Sudan Red 7B concentration increased. Furthermore, similar results have been obtained in previous studies when various dye markers such as Nile Blue A, Neutral Red, Sudan Red 7B, and Sudan Blue 35 were applied to $R$. flavipes (Atkinson, 2004; Grace and Abdallay, 1989, 1999).

In this regard, Delaplane et al. (1988) stated that as the concentration of the marking reagents increases, their uptake comparatively rises for the same amount of feed, which causes a reduction in the intestinal protozoa and impacts the digestion efficiency negatively.
Also, Grace and Abdallay (1989) stated that such a reduction in feed consumption depending on the concentration could be caused by the sublethal physiological effect and not by the behavioral avoidance of the marking reagents.

Therefore, this trend of decreased feed consumption according to the concentration increase appeared to be caused by sublethal physiological effects, such as the reduced number of intestinal protozoa, and further studies are needed to measure the changes in the number of intestinal protozoa right after the marking of the $R$. speratus for each concentration condition.

\subsection{Survival rate according to the concentration of the marking reagent}

The survival rate of the termites for 4 weeks after the forced feeding of the marking reagents containing different concentrations of Nile Blue A and Neutral Red was investigated (Fig. 6, 7).

For Nile Blue A, all concentration conditions showed approximately $90 \%$ survival rate until week 3 . and approximately $85 \%$ until week 4 (Fig. 6). The result from ANOVA on the survival rate of the control group and all the other treatment groups for each week in- 


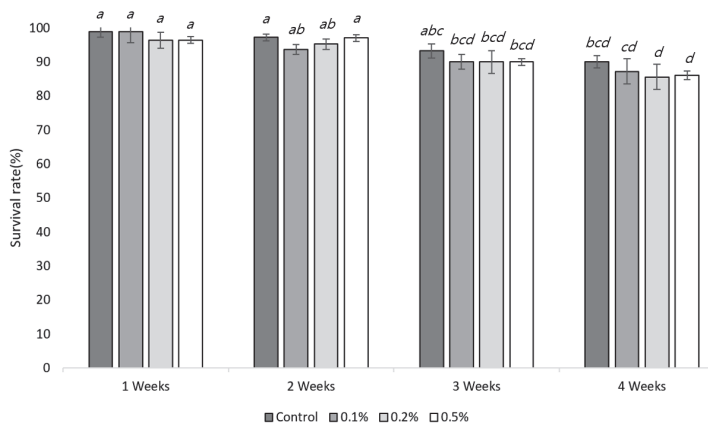

Fig. 6. Survival units (mean $\pm \mathrm{SD}$ ) for 4 weeks according to the concentration of Nile Blue A (ANOVA, Tukey post hoc test, $\alpha=0.05$ ).

dicated that the significance level was $<0.05(P>$ 0.05), which confirmed that there was no difference in the survival rate for all the groups. This result is also consistent with the study by Nobre (2007), which found that the survival rate of $R$. grassei when $0.2 \%$ and $0.5 \%$ of Nile Blue A were applied was maintained at $90 \%$, with no difference from the control group.

For Neutral Red treatment, the control group and all $0.1 \%-0.5 \%$ treatment groups demonstrated approximately $90 \%$ survival until week 3 (Fig. 7). However, $0.5 \%$ concentration condition decreased the survival rate to $84 \%$ after week 4 , which confirmed the presence of a difference between the control and treatment groups in the survival rate as per ANOVA (Fig. 7). Therefore, the application of $0.2 \%$ Neutral Red to $R$. speratus is considered appropriate.

According to the study by Nobre et al. (2007), the mortality rate of Neutral Red $0.5 \%$ stained $R$. grassei was approximately $35 \%$, which is three times higher than that of the control group. This mortality rate is much higher than that observed in the present study (about 16\%), and this difference could be due to the variation in the feeding sources during the 4 weeks of incubation after the staining. During the study by Nobre et al. (2007), nutritional deficiencies could have been caused in the termites as they were provided with

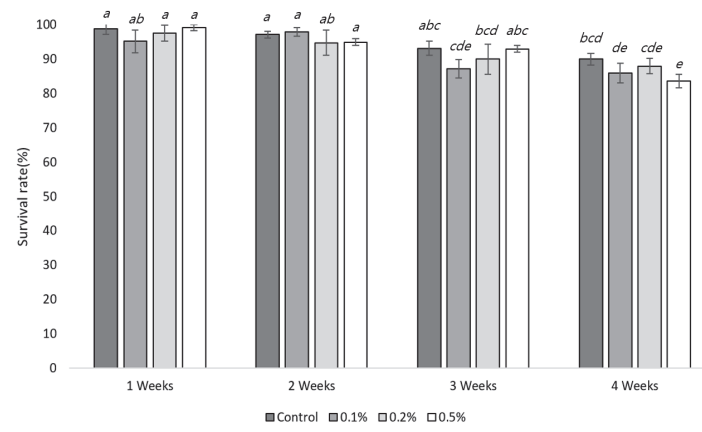

Fig. 7. Survival units (mean \pm SD) for 4 weeks according to the concentration of Neutral Red (ANOVA, Tukey post hoc test, $\alpha=0.05$ ).

only filter papers for 3 weeks; however, the termites were fed with a sawdust diet in the present study.

Additionally, when Im and Han (2020) applied Sudan Red 7B to $R$. speratus in the same environmental condition, the difference in survival rate of the control and treatment groups was clear after 10 days of staining. The survival rate of the treatment group was $<85 \%$, which is a limitation of the application of this dye. However, except for $0.5 \%$ Neutral Red, both dyes did not cause any difference in the survival rate between the groups, and a survival rate of $>90 \%$ was maintained even after 4 weeks. In conclusion, it was confirmed that Nile Blue A and Neutral Red do not affect the survival rate of $R$. speratus and could serve as appropriate dye markers for staining the subject.

\subsection{Retention time of the marking reagent}

After staining $R$. speratus for 5 days with Nile Blue $A$ and Neutral Red at each concentration condition $(0.1 \%, 0.2 \%$, and $0.5 \%)$, marking was persistently measured for 11 weeks while feeding Sawdust diet. Both Nile Blue A and Neutral Red exhibited a deeper color of marking as the concentration increased with visual observation over time. Additionally, none of the marked individuals in any of the conditions exhibited any 


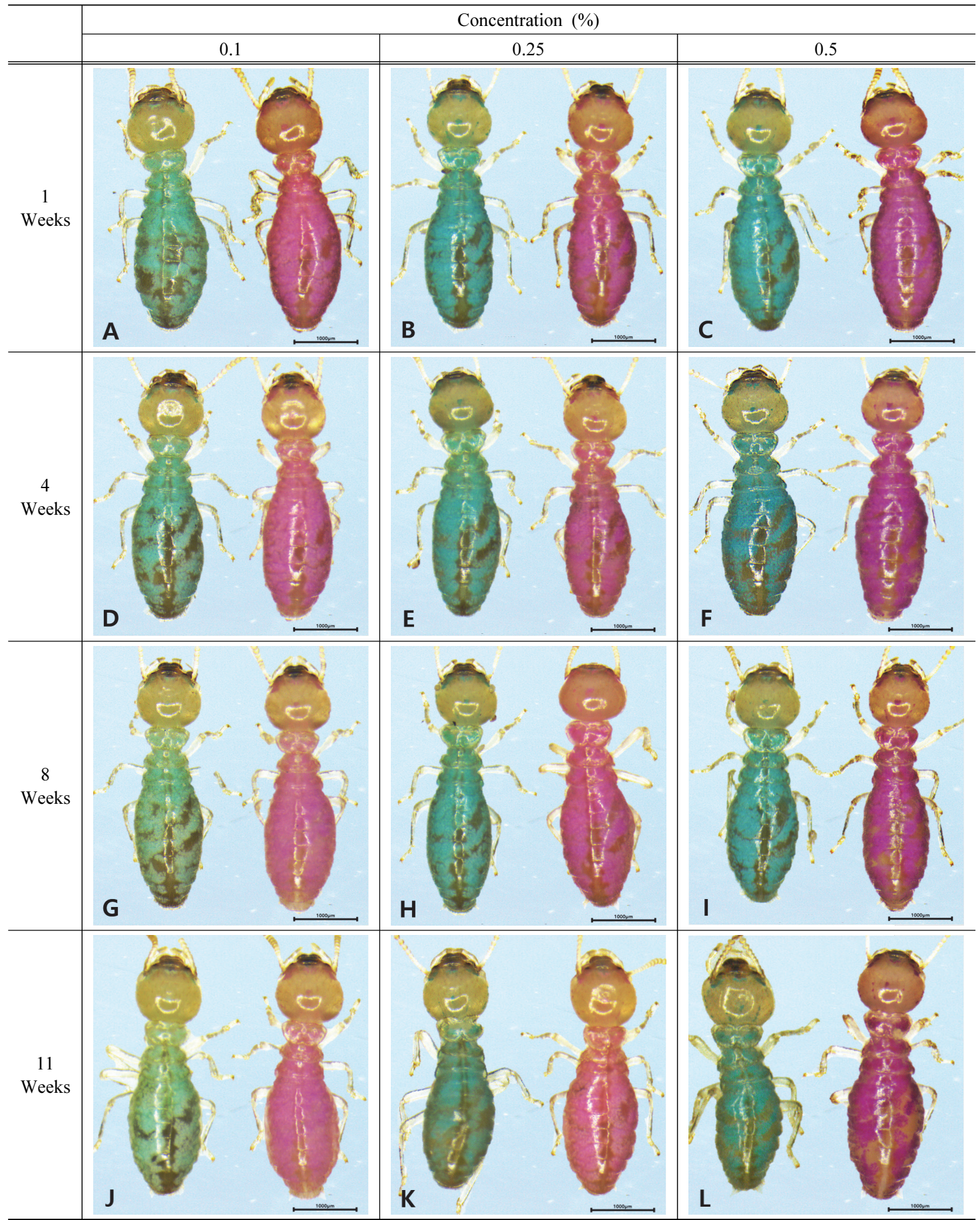

Fig. 8. Comparison of dye marking patterns by concentration conditions over time (A-C: initial, D-F: 4weeks later, G-I: 8weeks later, J-L: 11weeks later / Left: Nile Blue A, Right: Neutral Red). 
signs of fading after week 4 (Fig. 8). However, after week 8 , some of the individuals stained with $0.1 \%$ of the dye retained the marking (Fig. $8(\mathrm{G})$ ), while the marking of other individuals faded. This finding is consistent with previous studies stating that when $R$. flavipes and $R$. virginicus were stained with $0.1 \%$ Nile Blue A for 3 days and fed with a mixed-wood diet for 27 days (approximately 4 weeks), the marking faded and the marked individuals were measured as unmarked ones (Thorne et al., 1996). However, there was a difference in the fading time between the previous study and this one. In this study, the marking reagents were fed for 5 days, which resulted in a comparatively larger amount of the reagent to be accumulated in the body. Hence, even when stained with $0.1 \%$ of the dye, fading occurred only at 8 weeks, which is twice as long as the 4 weeks reported in the previous study.

Meanwhile, at all concentration conditions $>0.2 \%$ of Nile Blue A and Neutral Red, no sign of fading was observed in any of the marked individuals after week 11, and the marking was clearly persistent (Fig. 8 ). When compared with the study by Im and Han (2020) that showed 1 week (7 days) marking persistence of the $2 \%$ Sudan Red 7B, which was the highest concentration condition applied, this result demonstrated 11 times longer durability of the marking reagents. Therefore, the application of Nile Blue A and Neutral Red at $0.2 \%$ and $0.5 \%$ concentration conditions on $R$. speratus is suitable for the visual observation monitor- ing for the range of the subterranean termite colony areas. Thus, it is possible to apply the mark-release-recapture (MRR) method for monitoring via monitoring device round wooden structures.

\subsection{Transfer of the marking reagent}

Transfer effect through nutrient exchange between the marked and unmarked individuals in the same colony was measured (Table 1). Since there was no increase in the number of individuals stained with Nile Blue A and Neutral Red for 21 days, there was no transfer effect through trophallaxis. Furthermore, soldiers placed together did not exhibit any transfer effect. Similar results have been reported in a study by Evans (1997), which stated that once the marking reagents are accumulated in the lipids, transfer effect does not occur through trophallaxis.

Meanwhile, Nile Blue A and Neutral Red markings were retained by the individuals even after molting (Fig. 9). Since the fed marking reagents were dissolved in lipids that constituted the fat body of the termites (Evans, 1997), marking did not fade even after molting. In conclusion, while marking $R$. speratus with Nile Blue A and Neutral Red, the workers can transfer the marking reagent via nutrient exchange to soldiers. However, when the dyed workers are placed in the colony with soldiers, there is no transfer effect through nutrient exchange between the workers and soldiers.

Table 1. Change in the numbers of dyed and undyed R. speratus workers after mixing thirty workers fed Nile Blue A or Neutral Red

\begin{tabular}{|c|c|c|c|c|c|c|c|c|}
\hline \multirow{3}{*}{ Marking Regent } & \multicolumn{8}{|c|}{ Number of Dyed: Undyed Post-Exposure } \\
\hline & \multicolumn{2}{|c|}{ Initial } & \multicolumn{2}{|c|}{7 days } & \multicolumn{2}{|c|}{14 days } & \multicolumn{2}{|c|}{21 days } \\
\hline & Dyed & Undyed & Dyed & Undyed & Dyed & Undyed & Dyed & Undyed \\
\hline Nile Blue A & 30 & 30 & $29.7 \pm 0.5$ & $29.3 \pm 0.5$ & $28.7 \pm 0.9$ & $29.0 \pm 0.0$ & $28.3 \pm 0.5$ & $27.7 \pm 0.5$ \\
\hline Neutral Red & 30 & 30 & $29.3 \pm 0.9$ & $29.0 \pm 0.0$ & $28.3 \pm 0.5$ & $28.3 \pm 0.5$ & $28.3 \pm 0.5$ & $28.0 \pm 0.0$ \\
\hline
\end{tabular}



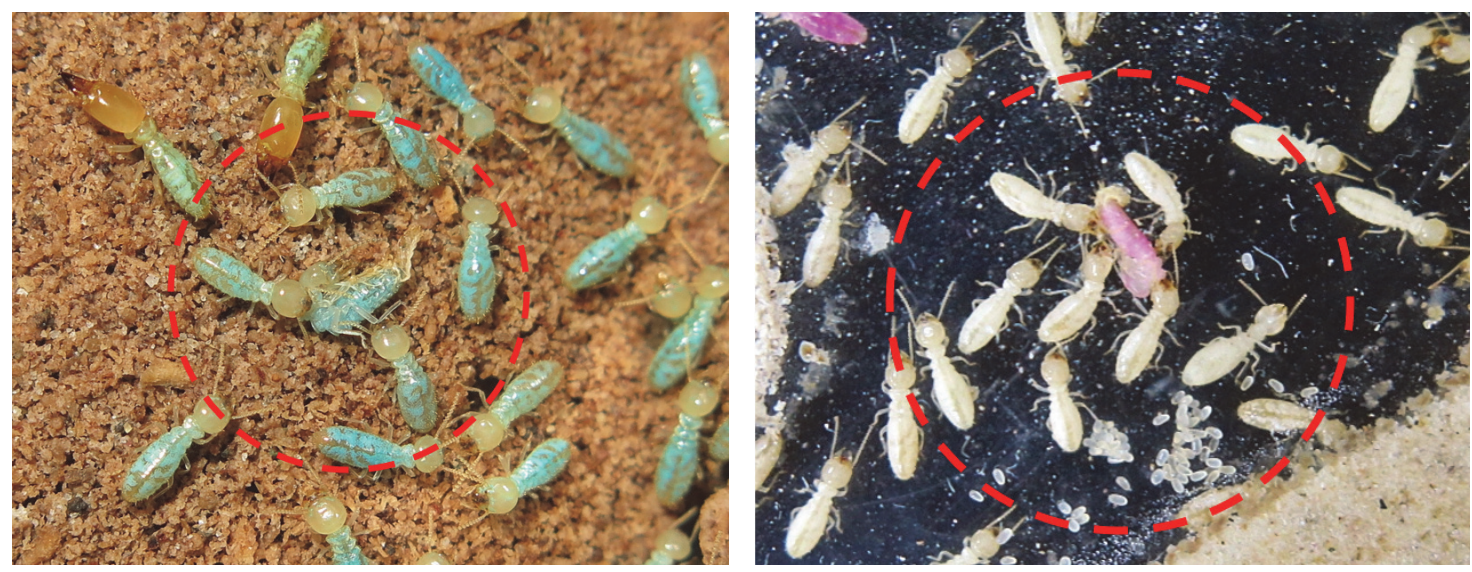

Fig. 9. Molting of dyed worker (Left: Nile blue A / Right: Neutral Red).

\subsection{Spread area coverage over time}

Five hundred marked individuals were placed in a planar arena with an $R$. speratus colony of approximately 25,000 termites to investigate the speed and area of spread of the marked ones (Fig. 10, 11). It was observed that the marked individuals moved a distance of up to $5 \mathrm{~m}$ within a day. Within 2 - 3 days, these individuals spread over a relatively wide range of up to 25-30 m, and a mixture of Nile Blue A and Neutral Red stained individuals released from each end was detected (Fig. 11(B)). After 6 days, the spread area of the marked individuals was $35-40 \mathrm{~m}$, which is the whole area of the arena.

Restricted laboratory conditions with limited foraging

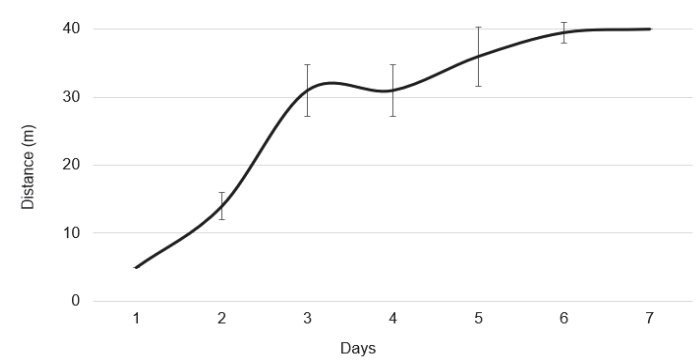

Fig. 10. Foraging range of marked individuals over time. arena space and containing a colony of approximately 25,000 R. speratus are different from the natural conditions of the $R$. speratus colony in terms of the number of colony members and the size of the habitat. Also, careful interpretation of this study results should be made since the length was measured in one-dimensional plane space. In contrast, the natural condition occurs in a three-dimensional range of area. The subterranean termites move around in the range of the colony area by tunneling in nature, and this study too observed the pattern of spread of the marked individuals through the tube connected to the planar arena over time. Thus, it could be concluded that the result of this study is not significantly different from the activity patterns of termites in their natural habitat.

Tusunoda (1999) reported that in nature, the $R$. speratus colony has an area range of approximately $10 \mathrm{~m}$ in a linear distance. However, previous studies (Paulmier et al., 1997; Grace et al., 1989; Grace, 1990; Su, 1993; Vargo, 2006) on Reticulitermes spp. other than $R$. speratus measured the foraging distance of colonies using dye markers in the field, and the reported linear distance varied from 30 to $122 \mathrm{~m}$, depending on the size and species of the colony (Table 2). According to such results, it is most likely that the 
Selection of Dye Markers for Monitoring Reticulitermes speratus and Identification of Colonies by Heterogeneous Dye-Marking
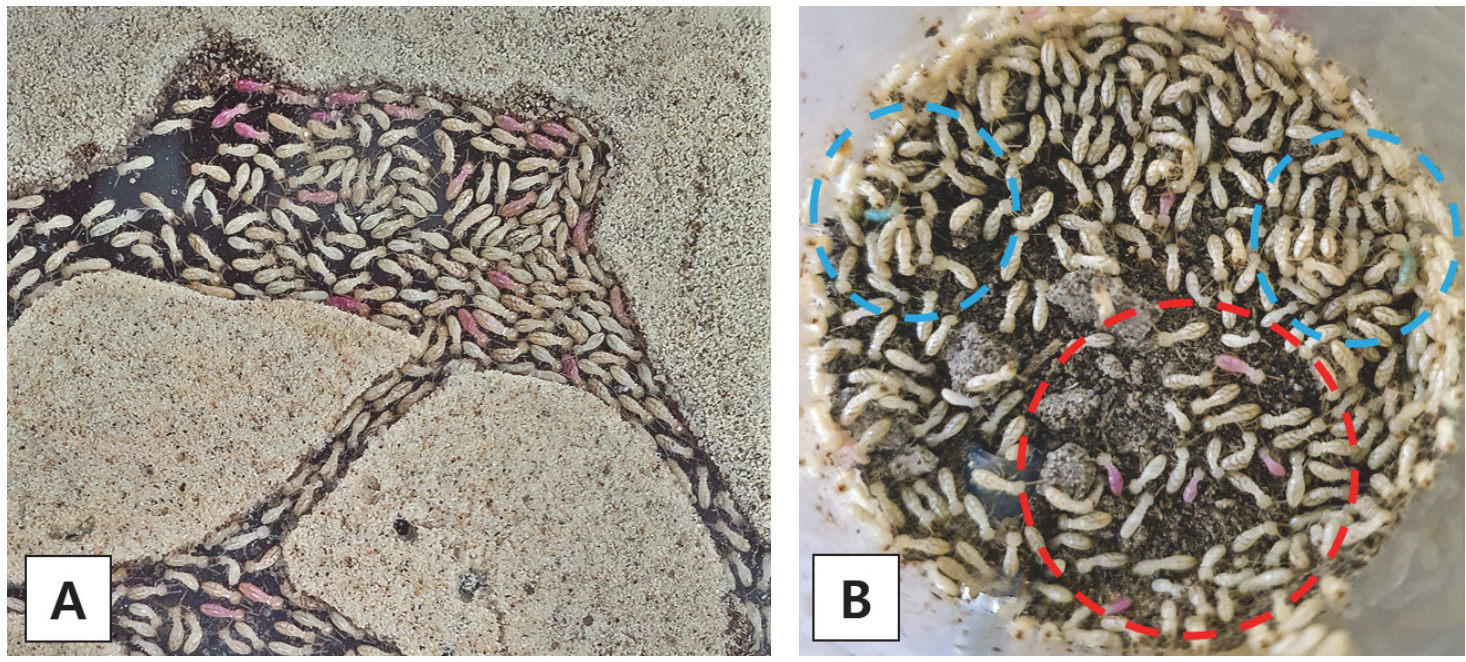

Fig. 11. Foraging pattern of the released dyed worker.

Table 2. Comparing the results of a prior study in the foraging distance according to the species of Reticulitermes spp.

\begin{tabular}{|c|c|c|c|}
\hline Species & Foraging Populations & Foraging Distance & Journal \\
\hline \multirow{6}{*}{ R. flavipes } & - & $23.5 \mathrm{~m}$ & Vargo, 2003 \\
\hline & - & $30 \mathrm{~m}$ & Vargo and Carlson 2006 \\
\hline & $720,000 \sim 940,000$ & $41 \mathrm{~m}$ & Grace, 1990 \\
\hline & $20,000 \sim 5,000,000$ & $71 \mathrm{~m}$ & Su et al., 1993 \\
\hline & $1,761,170 \sim 2,407,268$ & $48 \mathrm{~m}$ & \multirow{2}{*}{ Grace et al., 1989} \\
\hline & $2,581,197 \sim 3,793,879$ & $79 m$ & \\
\hline R. hageni & - & $30 \mathrm{~m}$ & Vargo and Carlson 2006 \\
\hline \multirow{2}{*}{ R. santonensis } & $1.070 .000 \sim 1,330,000$ & $65 \mathrm{~m}$ & \multirow{2}{*}{ Paulmier et al., 1997} \\
\hline & $216,000 \sim 244,000$ & $40 \mathrm{~m}$ & \\
\hline \multirow{2}{*}{ R. speratus } & - & $5 \mathrm{~m}$ & Nakajima and Mori, 1961 \\
\hline & $109,400 \sim 466,400$ & $10 \mathrm{~m}$ & Tsunoda et al., 1999 \\
\hline R. virginicus & - & $122 \mathrm{~m}$ & $\begin{array}{c}\text { Vargo, } 2003 \\
\text { Vargo et al., } 2006\end{array}$ \\
\hline
\end{tabular}

linear distance of the extent of the activity area for $R$. speratus colony in nature is $>10 \mathrm{~m}$.

\section{CONCLUSION}

It was confirmed that when different concentration conditions of Nile Blue A and Neutral Red are used to dye $R$. speratus, the amount of feed consumption decreases as the concentration increases. However, the body color is deepened since more marking reagents are accumulated in the body. Also, after assessing the survival rate, marking persistence, and transfer effect while feeding the termites with sawdust diet, $0.2 \%$ of Nile Blue A and Neutral Red appear to be appropriate 
for staining.

Termites stained with the two dye markers selected in this study, Nile Blue A and Neutral Red, could be clearly distinguished with visual observation. Thus, if individuals are collected from each end of the area where the subterranean termite infestation has been confirmed and marked with different dyes and released (application of MRR method) in the same way as in the foraging distance experiment of this study, it is possible to check the same colony according to the presence of the mixed marked individuals.

In the laboratory environment, the marked individuals were observed to spread to a distance of up to $40 \mathrm{~m}$ in 7 days. Therefore, when calculating the activity area of termites colony around the wooden structure through the monitoring device, it is necessary to observe the diffusion of marking units by recapturing them after sufficient time has elapsed after Mark-Release.

\section{ACKNOWLEDGMENT}

This study was carried out with the support of 'R\&D Program for Forest Science Technology (Project No. 2021327A00-2122-AA03) provided by Korea Forest Service(Korea Forestry Promotion Institute).

\section{REFERENCES}

Atkinson, T.H., Griffin, A.J., King, E.J. 2004. Laboratory and studies of a purple dye marker for Reticulitermes spp. (Isoptera: Rhinotermitidae). Sociobiology 43(2): 259-267.

Chouvenc, T., Bardunias, P., Li, H.F., Elliott, M.L., Su, N.Y. 2011. Planar arenas for use in laboratory bioassay studies of subterranean termites (Rhinotermitidae). Florida Entomologist 94(4): 817-826.

Chouvenc, T. 2018. Comparative impact of chitin synthesis inhibitor baits and non-repellent liquid termiticides on subterranean termite colonies over foraging distances: Colony elimination versus localized termite exclusion. Journal of Economic Entomology 111(5): 2317-232.

Chung, Y.J., Kim, S.H., Kim, Y.J., Yu, J.S. 2015. Applicability study on Reticulitermes speratus kyushuensis (Isoptera: Rhinotermitidae) colony eliminator to preserve wooden cultural heritage. Journal of the Korean Wood Science and Technology 43(6): 818-825.

Delaplane, K.S., Bourg, L.A., La Fage, J.P. 1988. Suppression of termite feeding by Sudan Red 7B. Inter. Res. Group on wood preserv. Doc. No. IRG/WP/1344: 4.

Evans, T.A. 1997. Termites (Isoptera: Rhinotermitidae \& Termitidae). Sociobiology 29(3): 277-292.

Evans, T.A. 2000. Fast marking of termites (Isoptera: Rhinotermitidae). Sociobiology 36(3): 517-523.

Forschler, B.T., Townsend, M.L. 1996. Mark-releaserecapture estimates of Reticulitermes spp. (Isoptera: Rhinotermitidae) colony foraging populations from Georgia. U.S.A.. Environmental Entomology 25(5): 952-962.

Grace, J.K., Abdallay, A., Farr, K.R. 1989. Eastern subterranean termite (Isoptera, Rhinotermitidae) foraging territories and populations in Toronto. The Canadian Entomologist 121(7): 551-556.

Grace, J.K. 1989. A modified trap technique for monitoring Reticulitermes subterranean termite populations (Isoptera Rhinotermitidae). Pan-Pacific Entomologis 65(4): 381-384.

Grace, J.K., Abdallay, A. 1989. Evaluation of the dye marker Sudan Red 7 B with Reticulitermes flavipes (Isoptera: Rhinotermitidae). Sociobiology 15(1): 71-77.

Grace, J.K. 1990. Mark-recapture studies with Reticulitermes flavipes (Isoptera: Rhinotermitidae). Sociobiology 16(3): 297-303.

Im, I.G., Han, G.S. 2020. Laboratory evaluation of the marking effect of Sudan Red 7B on subterranean termites (Reticulitermes speratus) in Korea. Journal of the Korean Wood Science and Technology 48(5): 
Selection of Dye Markers for Monitoring Reticulitermes speratus and Identification of Colonies by Heterogeneous Dye-Marking

745-754.

Im, I.G., Cha, H.S., Kang, W.C., Lee, S.B., Han, G.S. 2021. The status of damage and monitoring of subterranean termite (Reticulitermes spp.) (Blattodea: Rhinotermitidae) for wooden cultural heritage in Korea. Journal of Conservation Science 37(3): 191-208. Judd, T.M., Fasnacht, M.P. 2007. Distribution of micronutrients in social insects: A test in the termite Reticulitermes flavipes (Isoptera: Rhinotermitidae) and the ant Myrmica punctiventris (Hymenoptera: Formicidae). Annals of the Entomological Society of America 100(6): 893-899.

Kim, D.W., Jeong, S.H., Lee, S.H. and Chung, Y.J. 2010. Study on the adaption technique for detection of termites using microwave. Journal of Conservation Science 26(1): 77-83.

Kim, S.H., Lee, H.S., Lee, H.M., Hwang, W.J., Chung, Y.J. 2014. A study on the exploration of dyes for ecological study of termites in Korea. Journal of the Korean Wood Science and Technology Conference Proceedings, pp. 334-335.

Kim, S.H., Im, I.G., Chung, Y.J. 2020. Applicability evaluation of Nile Blue A dye to korean termite (Reticulitermes speratus kyushuensis). Journal of Conservation Science 36(5): 333-338.

Kim, Y.H., Lim, B.A., Lee, J.M., Jo, C.W., Kim, S.J., Park, J.H. 2019. A study on the inspection of termite-damaged wooden buildings through the use of detection dogs and an analysis of environmental factors. Journal of Conservation Science 35(6): 641-651.

Korea Forest Service, 2016, The status and control measures and implications of termites damage on wooden structures. Korea Forest Service 1-14.

Lee, G.S., Jeong, S.Y. 2004. Ecological characteristics of termite(Reticulitermes speratus kyushuensis) for preservation of wooden cultural heritage. Korean Journal of Cultural Heritage Studies 37: 327-348.

Lee, W., Choi, D.S., Ji, J.Y., Kim, N., Han, J.M., Park,
S.H., Lee, S., Seo, M.S., Hwang, W.J., Forschler, B.T., Takematsu, Y., Lee, Y.H. 2015. A new record of Reticulitermes kanmonensis Takematsu, 1999 (Isoptera: Rhinotermitidae) from Korea. Journal of Asia-Pacific Entomology 18(3): 351-359.

Matsuura, K., Nishida, T. 2001. Comparison of colony foundation success between sexual pairs and female asexual units in the termite Reticulitermes speratus (Isoptera: Rhinotermitidae). Population ecology 43(2): 119-124.

Nakajima, S., Mori, H. 1961. Knowledge of termite. Green-age, Tokyo. 346.

National University of Cultural Heritage Industrial Academic Cooperation Group. 2019. Cultural property care program result report.

Nobre, T., Nunes, L., Bignell, D.E. 2007. Estimation of foraging territories of Reticulitermes grassei through mark-release-recapture. Entomologia Experimentalis et Applicata 123(2): 119-128.

Paulmier, I., Vauchot, B., Pruvost, A.M., Lohou, C., Tusssac, M., Jequel, M., Leca, J.L. and Clement, J.L. 1997. Evaluation of two populations of Reticulitermes santonensis De Feytaud (Isoptera) by triple mark-recapture procedure. 28th Meeting International. Research Group on Wood Preservation 97-10237.

Son, D.W., Lee, D.H. 2008. Evaluation on termite damage of the traditional wooden building by non-destructive methods. Journal of the Korean Wood Science and Technology 36(1): 21-29.

Su, N.Y., La Fage, J.P., Esenther, G.R. 1983. Effects of a dye, Sudan Red 7B, on the formosan subterranean termite, Coptotermes formosanus Shiraki (Isoptera: Rhinotermitidae). Material and Organismen 18(2): 127-133.

Su, N.Y., Scheffrahn, R.H. 1986. A method to access, trap, and monitor field populations of the formosan subterranean termite (Isoptera: Rhinotermitidae) in the urban environment. Sociobiology 12(2): 299-304. 
Su, N.Y., Scheffrahn, R.H., Ban, P. 1988. Retention time and toxicity of a dye marker, sudan red $7 b$, on formosan and eastern subterranean termites (Isoptera: Rhinotermitidae). Journal of Entomological Science 23(3): 235-239.

Su, N.Y., Ban, P.M., Scheffrahn, R.H. 1993. Foraging populations and territories of the eastern subterranean termite (Isoptera: Rhinotermitidae) in southeastern florida. Environment Entomology 22(5): 1113-1117.

$\mathrm{Su}$, N.Y. 2005. Response of the formosan subterranean termites (Isoptera: Rhinotermitidae) to baits or nonrepellent termiticides in extended foraging arenas. Journal of economic entomology 98(6): 2143-2152.

Tamashiro, M., Fujii, J.K., Lai, P.Y. 1973. A simple method to observe, trap, and prepare large numbers of subterranean termites for laboratory and field experiments. Environmental Entomology 2(4): 721-722. Thorne, B.L., Russek-Coen, E., Forschler, B.T., Breisch, N.L., Traniello, J.F.A. 1996. Evaluation of markrelease-recapture methods for estimating forager population size of subterranean termite(Isoptera: Rhinotermitidae) colonies. Environment Entomology 25(5): 938-951.

Tsunoda, K., Matsuoka, H., Yoshimura, T. 1998. Colony elimination of Reticulitermes speratus (Isoptera: Rhinotermitidae) by bait application and the effect on foraging territory. Journal of Economic Entomology 91(6): 1383-1386.

Tsunoda, K., Matsuoka, H., Yoshimura, T., Tokoro, M. 1999. Foraging populations and territories of Reticulitermes speratus (Isoptera: Rhinotermitidae). Journal of Economic Entomology 92(3): 604-609. Vargo, E.L. 2003. Genetic structure of Reticulitermes flavipes and $R$. virginicus (Isoptera: Rhinotermitidae) colonies in an urban habitat and tracking of colonies following treatment with hexaflumuron bait. Entomological Society of America 32(5): 1271-1282. Vargo, E.L., Carlson, J.R. 2006. Comparative study of breeding systems of sympatric subterranean termites (Reticulitermes flavipes and $R$. hageni) in Central North Carolina using two classes of molecular genetic markers. Environmental Entomology 35(1): 173-187.

Vargo, E.L., Juba, T.R., Deheer, C.J. 2006. Relative abundance and comparative breeding structure of subterranean termite colonies (Reticulitermes flavipes, Reticulitermes hageni, Reticulitermes virginicus, and Coptotermes formosanus) in a South Carolina Lowcountry site as revealed by molecular markers. Annals of the Entomological Society of America 99(6): 1101-1109. 


\title{
APPENDIX
}

\author{
(Korean Version)
}

\section{Reticulitermes Speratus 군체의 모니터링을 위한 염색 시약 선정 및 이종 마킹을 통한 군체 간 식별}

\begin{abstract}
초록 : 국내 목조건축물을 가해하는 지중 흰개미인 Reticulitermes speratus 군체의 영역 범위 산정을 위한 적정 염색약 선정 및 확산 경향 평가를 실시하였다. Sawdust diet를 이용한 감수성 평가 결과, 염색약의 농도가 증가할수록 섭식량은 감소 하지만 보다 진하게 염색되었으며, 생존율은 Neutral Red $0.5 \%$ 를 제외하고 4주차까지 모든 농도 조건이 대조군과 차이 없이 $85 \%$ 이상의 생존하였다. 또한 2 가지 염색약 모두 $0.1 \%$ 농도 조건을 제외한 $0.2 \%$ 이상의 농도 조건에서 11 주 동안 염색이 유지되었고 전이력은 염색약 섭식 직후를 제외하고는 없는 것으로 확인되었다. 이에 따라 Nile Blue A와 Neutral Red 모두 $0.2 \%$ 농도 조건이 R. speratus 군체의 영역 모니터링에 최적의 농도라고 판단된다. 이와 더불어 실내 조건에서 제작된 $40 \mathrm{~m}$ 길이의 foraging arena에 약 25,000 마리 군체를 서식시킨 뒤, Nile Blue A와 Neutral Red $0.2 \%$ 농도로 각각 염색된 개체를 양 쪽 끝에 방사하여 시간 경과에 따른 확산 경향을 파악하였다. 그 결과 염색 개체가 7일 정도의 기간에 $40 \mathrm{~m}$ 거리까지 점진 적으로 확산 이동하여 서로 섞이는 것이 확인되었다. 이를 통해 목조건축물에 유입된 R. speratus 군체를 대상으로 Mark-Release-Recapture(MRR) 법을 이용한 모니터링을 실시할 경우, 군체의 영역 범위를 산정할 수 있으며, 서로 다른 군체 의 식별도 가능할 것이다.
\end{abstract}

\section{1. 서론}

국내 서식 지중 흰개미인 Reticulitermes spp.는 국내 여러 목조건축물들을 훼손시키고 있는 것이 여러 선행 연구 결과 확인되 었다(Kim et al., 2010; Lee and Jeong, 2004; Chung et al., 2015; Lee et al., 2015). 또한 최근 문화재 분야에서는 2018년 2019년 기준으로 전국 2,805 건의 조사 대상 목조문화재 중 486 건에서 지중 흰개미 가해흔이 발견되었으며, 이 중 약 $30 \%$ 는 가해가 진행 중인 것으로 확인됨에 따라 전국적으로 지중 흰개미에 의한 야외 목조문화재의 피해가 활발하게 진행 중인 것으로 파악되었 다(Im et al., 2021). 이러한 지중 흰개미의 특성 때문에 목조건축물의 구조적인 피해가 늘어남에 따라 검역 본부 위험관리과에서 는 국내 침입 및 정착 시, 피해 위험이 큰 고 위험 흰개미 28종을 선정하였으며(Korea Forest Service, 2016), 문화재청 산하 국립문화재연구소와 전국 17 개 시 · 도 23 개 문화재 돌봄사업단은 전국의 목조문화재 흰개미 피해 정기 모니터링을 실시하고 있다. 해당 기관들은 흰개미 탐지견, 극초단파 탐지 장비, 초음파 탐지 장비, Video Microscope, 말목 예찰기 설치, 가해흔 육안 관찰(Cultural Heritage Care Support Project, 2019; Kim et al., 2019; Son and Lee, 2008) 등을 지중 흰개미 모니터링에 적용 중이다.

하지만 이러한 국내 적용 지중 흰개미 모니터링 방안들로는 대상 목조건축물 주변의 지중에 터널링을 통해 침입하는 $R$. speratus 군체의 영역을 산정할 수 없어 유입된 군체의 영역 범위 모니터링 및 방제에 한계가 있다. 이러한 문제점들은 해결하기 위하여 1980년대 후반부터 국외에서는 흰개미 군체의 방제를 위한 활동 영역(Foraging Territory) 파악을 위해 모니터링 스테이 션을 이용한 조사를 진행하였고(Su et al., 1986; Grace, 1989, 1990; Thorne et al., 1996; Tsunoda et al., 1998, 1999), 이 과정에서 채집된 개체를 대상으로 다양한 색상의 염색약(Dye marker)을 적용하였다. 염색약 연구 초기였던 1980년대에는 Coptotermes formosanus, Reticulitermes flavipes 등의 주요 피해 종들을 대상으로 Sudan Red 7B의 농도별 적용 연구가 진행되 었다(Su et al., 1983, 1988; Grace and Abdallay, 1989). 이후 1990년대부터는 Coptotermes formosanus, Reticulitermes flavipes 에 대하여 Nile Blue A (Su et al., 1993; Grace, 1989, 1990; Forschler and Townsend, 1996; Thorne et al., 1996)와 Neutral Red (Evans, 2000; Nobre et al., 2007) 등의 여러 염색 시약에 대한 적용성 연구가 진행되었다. 그리고 Tsunoda et al. (1998, 1999)은 Reticulitermes speratus에 대하여 Nile Blue A $0.05 \%$ 를 적용하여 야외 군체의 영역 모니터링을 실시하였다.

한편 국내에서는 지중 흰개미 모니터링을 위한 염색 시약 선정과 관련하여, Kim et al. (2014)이 R. speratus에 대해 Nile Blue $\mathrm{A}$ 를 적용하여 생존률, 전이력, 적정 농도 등에 대하여 검토하였다. 또한 Kim et al. (2020)도 R. speratus에 대해 Nile Blue $\mathrm{A}$ 의 적용 가능성을 검토하였으나, 실제 지중흰개미들의 생활 환경과는 다르게 대기에 노출된 제한된 공간에서 실험이 진행됨으로써 전반적으로 생존률이 낮게 평가되었다는 한계를 가지고 있다. Im and Han (2020)은 R. speratus에 대해 Sudan 
$\operatorname{Red} 7 \mathrm{~B}$ 를 적용한 연구에서 지중 흰개미의 서식 환경을 고려한 평가 방안을 정립하였다. 하지만 연구 대상으로 적용한 Sudan Red 7B는 R. speratus에 대해 최고 농도 조건에서도 염색 유지 기간이 2주 이하로 나타남에 따라 국내 적용에는 적합하지 않음이 확인되었다.

따라서 본 연구에서는 R. speratus의 영역 범위 산정에 적합한 염색 시약의 종류와 적정 농도를 Im and Han (2020)에서 정립된 평가 방법에 따라 파악하고자 하였다. 평가 대상 염색 시약으로는 선행 연구에서 R. speratus에 적용되었던 적이 있는 Nile Blue A와 아직까지 적용된 적이 없는 Neutral Red에 대해 비교 검토하였다. 적정 농도를 파악하기 위하여 염색 시약의 농도는 $0.1-0.5 \%$ 범위를 적용하였다. 이와 더불어 염색약을 이용한 목조건축물 유입 지중 흰개미 군체의 영역 범위 모니터링 시, 방사된 개체들이 군체 내 모든 영역에 고르게 확산되는 적정 시간이 필요할 것으로 사료된다. 이를 위해 실내 조건에서 foraging arena를 제작하고 서로 다른 염색 개체를 방사하여 시간 경과에 따른 R. speratus 염색 개체의 확산 범위 및 혼합 양상을 관찰하고자 한다.

\section{2. 재료 및 방법}

2.1. 지중 흰개미 채집 및 종 동정 (Termite collection and DNA sequencing)

세종특별자치시 고운동 및 충청북도 청주시 소재 산림에서 흰개미 가해목을 채집하여 연구실 내 보관 용기에 보관하였다. 실험에 사용될 흰개미 개체들은 Judd and Fasnacht (2007)와 Tamashiro (1973)의 방법을 변형하여 다음과 같이 분리하였다. 실험 시작 직전에 보관 용기 내에 골판지(corrugated cardboard)를 일정 기간 넣어두어 흰개미가 골판지로 옮겨가도록 함으로써 용기 내 목재의 분해 없이 흰개미 분리가 가능하도록 하였다.

채집한 지중 흰개미의 mtDNA(미토콘드리아 DNA)는 DNeasy Blood \& Tissue Kit (SolGent Co., Ltd., Korea)를 이용하여 추출하였다. PCR은 Takara PCR Thermal Cycler Dice TP600 (Takara Bio Inc., Japan)과 LCO-1490 및 HCO-2198 프라이머 세트을 사용하였다. 채집한 지중 흰개미에 대한 mtDNA의 COI 바코드 서열을 얻기 위해 2x Uh-taq PCR Pre-Mix (SolGent Co., Ltd., Korea)를 사용하였다. COI 서열(658 bp)은 GenBank 및 BOLD 시스템(생명 데이터 시스템의 바코드)을 통해 확인하 였으며, 동정 결과, 실험에 사용된 지중 흰개미는 R. speratus로 동정되었다.

2.2. 지중 흰개미 염색 (Marking and Consumption of sample containing marking reagents)

국외 선행 연구를 참조하여 Nile Blue A (CAS Number: 3625-57-8, Sigma, St. Louis, Mo. USA)와 Neutral Red (CAS Number: 553-24-2, Acros Organics, New Jersey, USA)를 사용하였다(Nobre et al., 2007; Evans, 2000, 2006; Kim et al., 2020). 마킹(Marking)을 위한 염색 시료는 Im and Han (2020)과 동일하게 제작하였으며, R. speratus에게 적용된 염색약 종류별 농도 조건은 선행 연구에서 C. acinaciformis, C. lacteus, R. grassei 종에게 적용된 농도를 조사하여 $0.1 \%, 0.2 \%, 0.5 \%$ (Nobre et al., 2007; Evans, 2000)로 중량비(wt/wt)에 따라 희석하여 제조하였다.

마킹을 위한 실험 공간은 다음과 같이 제작하였다. 세척한 실리카 샌드를 증류수와 $10: 1(\mathrm{wt} / \mathrm{wt})$ 의 비율로 배합한 기질 (substrate) $35 \mathrm{~g}$ 을 직경 $90 \mathrm{~mm}$ Petri-dish에 넣고 그 위에 염색약을 함유한 시료를 놓는다. 이후 실험 공간에 일 흰개미 400마리씩 을 투입하여 5 일간의 강제 섭식(No-Choice) 조건으로 노출함으로써 흰개미가 농도 조건별 염색약에 의해 염색되도록 하였다. 각 실험은 조건별로 3 반복으로 5 회 실시하였으며, 총 15 반복의 측정값을 평균하여 결과값을 구하였다.

염색약의 종류별 농도에 따라 5 일 동안 섭식시킨 염색 시료(filter paper)를 대상으로 섭식량을 측정하였다. 5 일 동안의 섭식 기간이 지난 후 먹이 시료를 꺼내어 건조기에서 $60^{\circ} \mathrm{C}$ 조건으로 항량까지 건조한 뒤, 중량 측정하였다. 이후 염색약별 농도 조건에 따른 섭식량을 비교하여 농도 증가에 따른 섭식 양상을 확인하고자 하였다.

\section{3. 생존율 및 염색 지속 기간 (Survival rate and Retention time of marking reagent)}

염색약의 종류별 농도 조건에 따른 생존율(survival rate)을 확인하였다. $55 \mathrm{~mm}$ Petri-dish에 2.2와 동일한 조건으로 수분을 함유시킨 실리카 샌드를 $25 \mathrm{~g}$ 넣는다. 먹이원의 경우, Matsuura and Nishida (2001)과 같이 목분, 셀룰로오스 파우더 등을 혼합하여 제조한 Sawdust diet를 $5 \mathrm{~g}$ 씩 실리카 샌드 위에 먹이원으로 투입하였다. 2.2에서 조건별로 염색된 일 흰개미 50 마리를 투입시켰다. 뚜껑을 덮고 파라필름으로 밀봉하여 용기 내부의 수분 증발을 억제하였다. 1 주 간격으로 밀봉을 풀어 에어레이션 및 소진된 Sawdust diet를 투입하였다. 각 농도 조건별 반복 수는 20 회이며, 주차별로 5 개씩 임의로 골라 4 주간의 생존율을 확인하였다.

이와 더불어 염색약의 종류에 따른 농도 조건별 유지력을 확인하기 위하여 2.2 의 염색 방법과 실험 공간을 동일하게 구성하여 
Selection of Dye Markers for Monitoring Reticulitermes speratus and Identification of Colonies by Heterogeneous Dye-Marking

일 흰개미 200마리를 조건별로 투입하였다. 먹이원으로 Sawdust diet를 매주 $5 \mathrm{~g}$ 씩 투입하였다. 시간 경과 및 먹이 섭식에 따른 염색 유지력을 실체현미경(Nicon, JSMZ800N, JPN)으로 확인하였다. 염색 조건별로 염색 직후, 4,8 주차에 농도 조건별로 일개미를 채집하여 촬영을 실시하였다.

\section{4. 염색 전이 (Transfer effect)}

염색 개체와 무처리 개체 간 영양교환(Trophallaxis)에 의한 염색 전이 유무를 확인하였다. 염색 개체의 염색 농도는 Nile biue A와 Neutral Red 모두 $0.2 \%$ 농도 조건을 선정하여 실시하였다. 염색된 일개미 30마리와 무처리 일개미 30마리, 무처리 병정개미 3마리를 $55 \mathrm{~mm}$ 페트리 디쉬에 2.3 의 생존율 평가와 동일한 조건에 투입하였다. 먹이원으로 Sawdust diet를 급여하였 다. 21일 동안 7일 간격으로 페트리 디쉬 내부의 에어레이션 및 Sawdust diet 급여를 실시함과 동시에 염색된 일개미와 무염색 일개미의 개체 수 계측 및 병정개미의 염색 전이 양상을 관찰하였다.

\section{5. 시간 경과에 따른 확산 영역 (Spread area coverage over time)}

목조문화재 목부재 및 권역에 유입된 지중 흰개미 군체의 활동 영역 산정을 위해 활용되는 염색약의 적용 가능성을 확인하기 위해 Foraging arena를 제작하여 염색 개체의 시간 경과에 따른 확산 범위를 확인하였다. Main nest를 기준으로 4 방향으로 구성된 아레나는 하나의 튜브가 약 $5 \mathrm{~m}$ 의 길이이다. 한 방향은 4 개의 튜브로 연결되어 총 $20 \mathrm{~m}$ 의 길이이고 Main nest를 기준으로 양쪽의 총 길이는 $40 \mathrm{~m}$ 이다(Fig. 1, 2).

Main Nest의 경우, 직경 $100 \mathrm{~mm}$, 높이 $110 \mathrm{~mm}$ 의 용기에 Saw dust diet $250 \mathrm{~g}$ 채워 넣어 흰개미 군체의 지속적인 먹이원으로 제공하였다. 그 위에 $3.5 \%$ agar를 높이 $10 \mathrm{~mm}$ 만큼 부어 Saw dust diet표면의 미생물 발아를 최대한 억제하였다.

Shelter는 직경 $45 \mathrm{~mm}$, 높이 $85 \mathrm{~mm}$ 의 플라스틱 원통형 컬럼으로 바닥면 중앙과 바닥면으로부터 $30 \mathrm{~mm}$ 높이 지점에 hole을 뚫었다(Fig. 1S). Shelter는 $5 \mathrm{~m}$ 간격으로 설치된 Planar arena의 모서리 부분에 설치하여 중간 서식처 역할을 수행한다. 각 Shelter 내부에는 Saw dust diet $30 \mathrm{~g}$ 을 채워 넣어 충분한 먹이 공급량 및 활성을 유지하도록 하였다. 먹이 시료 위에는 Main Nest와 동일하게 agar를 부었다. Shelter 벽면 hole에는 flexible plastic tube를 연결하여 인공적인 이동통로를 만들어 아레나 전체가 하나의 군체로 연결되도록 하였다.

내부에 유입된 지중 흰개미의 움직임을 관찰할 수 있는 Screen인 Planar arena는 C. formosanus를 대상으로 수행된 선행 연구(Su, 2005; Chouvenc et al., 2011; Chouvenc, 2018)의 실험 방법에 따라 R. speratus의 서식 특성에 맞게 변형하여 제작하였 다. 2 개의 $2 \mathrm{~mm}$ 두께 투명 아크릴 판(가로 $\times$ 세로 $150 \mathrm{~mm} \times 150 \mathrm{~mm}$ ) 사이에 $1 \mathrm{~mm}$ 투명 아크릴 판을 샌드위치 형태로 끼워 내부로 흰개미개체들이 활동할 수 있는 공간을 만들어 주었다. 위쪽 $2 \mathrm{~mm}$ 아크릴 판의 경우, Shelter와 접하는 부분에 hole을 뚫어 흰개미가 내부로 유입될 수 있도록 하였다. Planar arena 내부에는 중량에 약 $10 \%$ 증류수를 주입한 실리카 샌드 (Silica sand No 7, Saeron Industry, KOR)를 $30 \mathrm{~g}$ 투입하였다. 이를 통해 내부 습도를 일정하게 유지시켜 개체들이 Planar arena를 통해 여러 shelter를 지나다니며 실험 기간 동안 활동 할 수 있도록 하였다.

Foraging arena에 R. speratus colony 25,000마리를 Main nest 및 Shelter에 33개 그룹으로 나눠 투입하였다. 7일 동안 Foraging arena 전체가 연결될 때까지 모니터링한 후, Nile Blue A와 Neutral Red $0.2 \%$ 로 염색한 개체 500 마리를 Planar arena의 양끝 Shelter에 색상을 구분하여 각각 투입하였다(Fig. 1(A), 1(B)). 이를 통해 일차별 염색 개체의 확산 범위와 투입 지점과 반대 지점인 $40 \mathrm{~m}$ 까지의 도달하는 기간을 확인하였다. 1개의 Foraging arena Nile Blue A와 Neutral Red를 각각 투입하여 확산 경향을 확인하는 방법으로 총 5 회 반복 실험하였다.

\section{6. 데이터 분석 (Data analysis)}

염색약의 종류 및 농도 조건별 시료의 섭식량, 농도 조건별 생존율을 대상으로 SPSS Statistics 프로그램(IBM SPSS Statistics 26 , USA)을 사용하여 ANOVA 분석을 실시하였다. ANOVA 분석 시, 처리 평균 간에 유의성이 있을 경우 서로 다른 문자(a-e)로 표시하였다. 사후 비교 방법은 Tukey HSD post hoc을 수행하였다. 분석 결과는 평균 \pm 표준편차(Standard Deviation)로 나타냈다.

\section{3. 결과 및 고찰}

3.1. 염색 양상 및 시료 섭식량 (Marking and Feed Consumption of sample containing marking reagent)

Nile Blue A와 Neutral Red를 $0.1 \%, 0.2 \%, 0.5 \%$ 의 농도 조건으로 5 일 간 염색시킨 직후 관찰한 결과는 다음과 같다. 2 가지 염색약 모두 대조군과 비교할 때, $0.1 \%$ 농도 조건에서도 육안으로 염색 개체의 구분이 가능하였다(Fig. 3). 이는 섭식된 염색약이 
흰개미 체내 fat body의 구성 세포인 trophocytes의 지질(lipid)에 녹아 저장되어 축적됨에 따른 것으로 판단된다(Evans, 1997). 5 일 간의 염색 기간 동안 모든 염색 조건에서 극소수의 무염색 개체가 발견되었는데, 이는 탈피 전(pre-molting) 단식(fasting) 또는 생리적인 이유 때문인 것으로 판단된다(Su et al., 1983).

한편 병정개미(soldier)의 경우, 모든 염색 조건에서 5 일 간 염색 후에는 일개미와 동일하게 염색되었다(Fig. 4). 병정개미도 일개미와 마찬가지로 고농도로 갈수록 점점 진하게 염색되었으며, 이는 일개미가 병정개미에게 영양교환으로 영양원과 함께 염색 시약을 전달하기 때문이다. 또한 이러한 결과는 Reticulitermes speratus, Coptotermes frenchi, C. lacteus, Nasutitermes exitiosus 등을 대상으로 Nile blue A의 적정 농도를 연구한 선행 연구의 결과와 일치한다(Evans, 1997; Kim et al., 2020).

Nile Blue A와 Neutral Red 모두 농도가 증가함에 따라 강제 섭식(No-Choice) 조건임에도 대조군의 섭식량 대비 76 88\% (0.1\% 농도 조건), $46-61 \%$ ( $0.2 \%$ 농도 조건), $18 \sim 29 \%$ ( $0.5 \%$ 농도 조건) 정도로 섭식량이 감소하는 경향이 확인되었다(Fig. 5). 또한 ANOVA 분석 결과에서도 대조군과 농도별 섭식량에 차이가 있음이 확인되었다. 이에 따라 2가지 염색약 모두 종류에 상관없이 R. speratus에게 농도 증가에 따른 섭식량 감소가 나타난 것으로 판단된다.

이러한 농도 증가에 따른 섭식량의 감소 경향은 Im and Han (2020)에서 R. speratus를 대상으로 Sudan Red 7B를 농도별로 섭식시킨 결과와 일치한다. 또한 R. flavipes를 대상으로 Nile Blue A, Neutral Red, Sudan Red 7B, Sudan Blue 35 등의 다양한 염색약을 적용한 선행 연구에서도 동일한 결과가 확인되었다(Atkinson, 2004; Grace and Abdallay, 1989, 1999).

이에 대해 Delaplane et al. (1988)는 염색 시약의 농도 증가에 따라 동일 시료 섭식량 대비 상대적으로 많은 염색 시약 섭취로 인해 장내 원생동물(intestinal protozoa)이 감소하면서 소화 효율이 떨어짐에 따른 것이라고 언급하였다. 이와 더불어 Grace and Abdallay (1989)도 마찬가지로 농도가 증가함에 따라 대조군보다 섭식량이 점점 크게 감소하는 결과는 염색 시약에 대한 기피 반응(Behavioral avoidance)이 아닌 생리적 효과(sublethal physiological effect)인 것으로 판단된다고 하였다.

따라서 염색약 농도 증가에 따른 섭식량의 감소는 장내 원생 동물의 감소와 같은 생리적 원인에 의한 것으로 판단되며, 향후 연구에서는 R. speratus 개체의 염색 직후, 농도 증가에 따른 장내 원생동물의 차이 확인 필요할 것으로 판단된다.

\section{2. 생존율 (Survival rate according to the concentration of the marking reagent)}

Nile Blue A와 Neutral Red를 함유한 농도 조건별 시료를 강제 섭식 시킨 후, 시간 경과에 따른 흰개미의 생존율을 4주간 조사하였다(Fig. 6, 7).

Nile Blue A의 경우, 모든 농도 조건에서 3주차까지 약 $90 \%$, 4주차에는 약 $85 \%$ 이상의 생존율을 나타냈다(Fig. 6). 각 주차별 대조군과 농도 조건별 생존율을 ANOVA 분석한 결과, 모든 조건에서 유의 수준 0.05 미만 $(P>0.05)$ 으로 확인되어 대조군과 각 농도별 개체들의 생존율에 차이가 없음이 확인되었다. 이는 Nobre (2007)의 결과와 같이 3주차 까지 R. grassei에 대해 Nile Blue A $0.2 \%$ 와 $0.5 \%$ 농도 조건의 생존율이 $90 \%$ 이상으로 유지되며 대조군과 차이가 없었던 결과와 일치한다. 따라서 본 평가의 결과에 따라 R. speratus를 대상으로 Nile Blue $\mathrm{A}$ 를 적용할 경우, $0.5 \%$ 농도 조건까지 염색약에 의한 생존율의 영향 없이 적용이 가능한 것으로 판단된다.

Neutral Red의 경우, 3 주차까지 대조군과 0.1-0.5\%의 모든 농도 조건에서 약 $90 \%$ 이상의 생존율을 나타냈다(Fig. 7). 하지만 $0.5 \%$ 농도 조건의 경우에는 4주차가 경과하자 생존율이 약 $84 \%$ 정도로 감소하며 ANOVA 분석에서 대조군과 그룹 간 차이가 있음이 확인되었다(Fig. 7). 따라서 Neutral Red를 R. speratus에게 적용할 경우, $0.2 \%$ 농도 조건까지만 적용하는 것이 바람직 할 것으로 사료된다.

Nobre et al. (2007)은 Neutral Red $0.5 \%$ 조건으로 염색한 R. grassei의 사멸율이 대조군의 3 배 이상인 약 $35 \%$ 라고 보고하였 고, 본 연구의 결과(약 $16 \%$ ) 보다 훨씬 높았다. 이러한 사멸율의 큰 차이는 염색 이후 4 주의 배양 기간 동안의 먹이 차이에 기인한 것으로 판단된다. 본 연구에서는 Saw dust diet를 먹였으나, Nobre 등의 연구에서는 3주 동안 필터페이퍼만을 먹임으로써 영양 결핍이 발생하였을 것으로 추정한다.

이와 더불어 Im and Han (2020)에서 동일한 환경 조건으로 Sudan Red 7B를 R. speratus에게 적용한 결과, 염색 후 10일 후에 적용 대조군과의 생존율 차이가 뚜렷하게 나타나며 $85 \%$ 미만의 생존율을 보여 적용에 한계가 있었다. 하지만 Nile blue A 및 Neutral Red의 경우에는 Neutral Red $0.5 \%$ 를 제외하고는 4주가 경과하여도 생존율이 $90 \%$ 이상을 유지하여 대조군과 큰 차이를 보이지 않았다. 결론적으로 Nile Blue A 및 Neutral Red는 R. speratus의 생존율에 영향을 끼치지 않는 것으로 확인되어 염색 시약으로 적용이 가능할 것으로 판단된다. 
Selection of Dye Markers for Monitoring Reticulitermes speratus and Identification of Colonies by Heterogeneous Dye-Marking

\section{3. 염색 지속 기간 (Retention time of marking reagent)}

R. speratus를 5 일 간 Nile Blue A, Neutral Red를 농도 조건( $0.1 \%, 0.2 \%, 0.5 \%)$ 에 따라 염색시킨 뒤, Sawdust diet를 섭식시키 며 주차별 염색 지속성을 11 주간 확인하였다. Nile Blue A와 Neutral Red 모두 모든 농도가 증가할수록 시간 경과에 후에도 육안관찰에서 더 짙은 색상이 확인되었다. 이와 더불어 모든 조건에서 4 주 경과 시에도 염색 개체들에게서 fading이 관찰되지 않았다(Fig. 8). 그러나 8 주가 경과 후, $0.1 \%$ 농도 조건에서 대부분의 개체의 염색이 유지되었지만(Fig. $8(\mathrm{G})$ ), 일부 개체에서 염색이 fading 되었다. 이러한 결과는 Nile Blue $\mathrm{A}$ 를 $0.1 \%$ 농도에서 3 일 동안 염색시킨 R. flavipes와 R. virginicus에게 mixed wood diet를 섭식시킨 지 27일(약 4주) 후에는 무처리 개체로 계측될 만큼 fading되었다고 언급한 부분과 일치한다(Thorne et al., 1996). 하지만 본 연구 결과와 선행 연구의 fading 관찰 시기에서 차이가 확인되었다. 본 연구의 실험 개체들의 경우 5 일 동안 염색약을 섭식시켰기 때문에 상대적으로 많은 염색약이 체내에 축적되었다. 이에 따라 선행 연구의 4 주보다 2 배 긴 8 주 경과 후에 $0.1 \%$ 농도 조건에서 염색이 fading 된 것으로 판단된다.

한편 $0.2 \%$ 이상의 농도 조건에서는 Nile Blue A와 Neutral Red 모두 11주 이후에도 전체 염색 개체에게서 fading 없이 모든 개체에서 선명하게 염색이 지속되었다(Fig. 8). 이러한 결과는 Sudan Red 7B를 농도별로 적용한 Im and Han (2020)의 연구에서 최고 농도인 $2 \%$ 조건이 1 주(7일) 정도의 지속성을 갖는 것과 비교할 때 11 배 이상의 긴 지속성을 갖는 것이다.

이에 따라 Nile Blue A와 Neutral Red의 $0.2 \%$ 와 $0.5 \%$ 로 염색시킨 R. speratus는 육안관찰을 통한 지중 흰개미 군체의 영역 범위 모니터링에 적용할 수 있을 것으로 판단된다. 즉, 목조건축물 주변에 설치된 예찰기를 활용한 마킹-방사-재채집 (Mark-Release-Recapture, MRR) 방법을 통한 모니터링이 가능하다.

\section{4. 염색 전이 (Transfer of marking reagent)}

동일 군체에서 염색 개체와 무처리 개체 간의 영양교환에 의한 염색 전이 효과를 확인하였다(Table 1). Nile Blue A와 Neutral Red 모두 21 일의 기간 동안 염색 개체의 증가 양상이 확인되지 않아 영양교환에 의한 전이 효과가 없었다. 또한 함께 투입한 무염색 병정개미에게도 전이되지 않았다. 이와 같은 결과는 Evans (1997)가 염색약이 지질에 흡수되어 축적된 후에는 영양교환에 의한 염색 전이가 발생되지 않는다고 언급한 결과와 일치한다.

한편 Nile Blue A와 Neutral Red 염색 개체 모두 탈피(molting) 이후에도 염색이 유지되었다(Fig. 9). 섭식을 통해 흡수된 염색약은 흰개미 체내의 fat body를 구성하는 지질(lipid)에 용해되어 축적되기 때문에(Evans, 1997), 염색 개체가 탈피한 후에도 색 빠짐이 일어나지 않는 것으로 판단된다.

결론적으로 염색 시약 Nile Blue A와 Neutral Red로 R. speratus를 염색할 경우, 일개미가 염색 시약을 섭식하는 동안에는 영양교환을 통해 병정개미에게 염색 시약의 전이가 가능하다. 하지만 염색된 일개미를 병정개미가 있는 군체에 투입할 경우, 일개미와 병정개미간의 영양교환에 의한 염색 전이는 일어나지 않는다.

\section{5. 시간 경과에 따른 확산 영역 (Spread area coverage over time)}

약 25.000 마리의 R. speratus 군체가 투입된 planar arena에 500마리의 염색 개체 투입을 통해 시간 경과에 따른 염색 개체들의 확산 속도 및 범위를 조사하였다(Fig. 10,11). 1일 이내에 $5 \mathrm{~m}$ 범위까지 투입된 염색 개체들이 이동하는 것을 확인하였다. 이후 2일 - 3일 이내에 $25 \mathrm{~m}-30 \mathrm{~m}$ 까지 비교적 넓은 범위로 개체들이 확산되면서 양쪽 끝에 방사된 Nile Blue A와 Neutral Red 염색 개체 간 혼합이 확인되었다(Fig. 11(B)). 6일 이후에는 염색 개체가 $35 \mathrm{~m}-40 \mathrm{~m}$ 의 전 범위로 확산되었다.

실험실 조건인 Foraging arena의 제한적인 공간과 약 25,000 마리 정도의 군체로 평가를 진행하는 것은 자연 상태의 $R$. speratus 군체의 개체 수, 서식처의 크기 등에서 차이가 있을 수 있다. 또한 관찰 결과는 1 차원 평면 공간의 길이 측정을 통한 확산 범위이므로, 곧바로 자연 상태의 3 차원적인 영역 범위로 해석하는 것은 경계해야 한다. 자연계에서도 지중 흰개미는 터널링을 통해 형성된 군체의 영역 범위 내에서 움직이고 있다. 본 연구는 planar arena를 통해 튜브를 통해 이어진 이동통로를 통해 염색 개체가 확산되는 경향을 시간 경과에 따라 확인한 것이다. 따라서 본 연구의 결과는 자연 상태의 지중 흰개미 군체에서 나타나는 흰개미의 활동 양상과 큰 차이가 없을 것으로 판단된다.

한편 Tsunoda (1999)는 R. speratus 군체가 자연 상태에서 직선거리로 약 $10 \mathrm{~m}$ 정도의 영역 범위를 갖는다고 보고하였다. 하지만 R. speratus 외에 국외의 Reticulitermes spp.을 대상으로 현장에서 염색약을 이용한 군체 단위의 foraging distance를 산정한 선행 연구(Paulmier et al., 1997; Grace et al., 1989; Grace, 1990; Su, 1993; Vargo, 2006)에서는 군체의 크기와 종에 따라 직선 거리가 약 $30 \mathrm{~m}-122 \mathrm{~m}$ 까지 다양하게 보고되었다(Table 2). 이들 결과들로 미루어 볼 때 R. speratus 군체의 경우에도 자연계에서의 활동 범위는 직선거리 $10 \mathrm{~m}$ 보다도 더 연장될 가능성이 있다. 


\section{4. 결론}

R. speratus를 Nile Blue A와 Neutral Red로 농도를 달리하여 염색한 결과, 염색약의 농도 증가함에 따라 시료의 섭식량은 감소하였으나, 더 많은 염색 성분들이 체내에 축적되어 체색(Body color)이 더욱 짙어 졌다. 또한 Saw dust diet를 급여하며 생존율, 지속성, 전이력을 평가한 결과, Nlie Blue A와 Neutral Red 모두 $0.2 \%$ 의 농도로 염색하는 것이 가장 적절할 것으로 판단된다.

이번 연구를 통하여 선정된 청색 계열(Nile Blue A)과 적색 계열(Neutral Red)의 2가지 염색 염색 시약으로 염색한 개체들은 육안 관찰에서도 뚜렷하게 구분된다. 따라서 이번 연구의 foraging distance 실험 방법과 동일하게 지중 흰개미의 유입이 확인된 영역의 양쪽 끝에서 채집한 개체를 색상을 달리하여 염색한 뒤 재방사한다면(다시 말해 MRR법 적용), 염색 개체의 혼합 유무에 따라 동일 군체 여부를 확인할 수 있다.

실험실적 방법에서 염색 개체가 7일 정도의 기간 동안에 $40 \mathrm{~m}$ 거리까지 점진적으로 확산 이동하는 것이 확인되었다. 따라서 실제 목조건축물 주변 예찰기를 통해 영역 산정을 할 때에는, 예찰기에서 채집된 개체의 염색 및 재방사 후 확산을 위한 충분한 시간이 경과한 후에 염색 개체의 확산 여부를 관찰하여야 한다. 